\title{
Insecticidal Activity of Some Chemicals of Mosquitoes Culex pipiens molestus Forskal
}

Aulfat Tahseen Yaseen*

Khalida Abdullah Sulaiman

Department of Biology, College of Sciences, University of Mosul, Mosul, Iraq

*Corresponding author: alfsbio76@uomosul.edu.iq ${ }^{*}$, Kalsbio69@uomosul.edu.iq

*ORCID ID: https://orcid.org/0000-0002-9805-3236, https://orcid.org/0000-0002-3363-3678

\author{
Received 22/5/2020, Accepted 25/11/2020, Published 30/3/2021
}

\begin{abstract}
:
The chemicals materials were used to study the effect of citric acid, detergents, sodium carbonate, sodium bicarbonate on the vitality of the third stage of mosquito Culex pipiens molestus. The highest larvicidal efficacy was established from citric acid solution followed by detergents solution, sodium carbonate, sodium bicarbonate with $\left(\mathrm{LC}_{50}\right)$ values $2096,2715,13930,13960 \mathrm{ppm}$ respectively. The concentration of $1000 \mathrm{ppm}$ of citric acid showed a fatal effect on the third stage larvae of mosquitoes which gave a mortality percent of $100 \%$ on the second day of the treatment. It was followed by the concentrations of $750 \mathrm{ppm}$ and $500 \mathrm{ppm}$ respectively which caused the death of all larvae on the fifth and sixth days respectively. On the other hand, the concentration of $1500 \mathrm{ppm}$ for the detergents killed $100 \%$ of the larvae on the third day of treatment. Then, it was followed by the concentration of $1000 \mathrm{ppm}$, leading to the destruction of all the larvae on the fifth day of the exposure. As for the use of sodium carbonate, the mortality percentage reached to $100 \%$ at a concentration of $8000 \mathrm{ppm}$ on the third day of treatment followed by the concentration of $6000 \mathrm{ppm}$, which led to a $100 \%$ killing rate on the sixth day of treatment. While the less impact of studied chemicals was sodium bicarbonate, the $8000 \mathrm{ppm}$ concentration of which caused $84.21 \%$ mortality rate of larvae on the fourth day of treatment.
\end{abstract}

Key words: Citric acid, Detergents, Larvae, Mosquito, Sodium carbonate, Sodium bicarbonate.

\section{Introduction:}

Female mosquitoes attack animals to obtain the blood which is necessary to form eggs. Some diseases transmitted by mosquitoes include yellow fever, malaria, dengue, Lymphatic filariasis and zika according to the WHO report (2). Malaria, the leading cause of mortality in Nigeria causes (1-2) million death (3). The medical value of mosquito as vectors of serious diseases that cause mortality, morbidity, economic loss and social confusion (4). $C x$. pipiens molestus appears to have a limited impact on the transmission of viruses in Europe. The highest form of these is West Nile Virus (WNV), which has been present in this area for at least twenty years (5). The mosquitoes are originated in Africa, but are now found in sub-tropical and tropical regions throughout the world (6).

The successful use of active components depends on its correct formulation into an equipment which can be applied for output protection with safety to those applying materials to the environment and to human, and animal life (7-9). Researchers have recently turned to the use of alternatives to pesticides that are effective against insects that remain for a short period and are safe and cheap, such as inorganic salts and antioxidants. The precise preparation of these materials leads to the eradication of insects and achieves the goal in small quantities and in a safe materials leading to the eradication of insects in a safe manner that does not harm human health $(10,11)$.

Mosquito control is carried out by habitat control, use of insecticides, larvicides. In this situation, safe larvicides were needed for human. Some chemicals and natural substances combat larvae of mosquitoes, one of which is detergents. Detergents are one of cleansing agents used in households. They are available having the potential to function like larvicide for mosquitoes. Some studies showed that detergents could inhibit oviposition and kill the larvae of mosquitoes in different concentrations (12). Detergents and soaps are used for pest control, 
many of which are liquids that perform better as insecticides and miticides (13). The present study was carried out in order to find the lethal concentrations of some chemicals solutions for killing of mosquitoes.

The aim of this study is to investigate some available, cheap and safe chemicals such as (citric acid, detergents, sodium carbonate, sodium bicarbonate) that are harmless towards human, animals and environment in addition to being effective in mosquitoes control.

\section{Materials and Methods: \\ Preparation of mosquitoes culture}

Mosquitoes eggs rafts were collected from the culture of $C x$. pipiens molestus $\mathrm{F}$. and transferred to the laboratory of entomology in University of Mosul College of Science in September of 2018. The collected egg rafts were put in a plastic container (enamel trays) containing 2 liters of dechlorinated tap water with (two egg rafts) per tray. The larvae were fed on rabbits food by mixing yellow corn $\% 25$, wheat $\% 25$, protein $\% 40$ and dry milk \%10 (2.3 g per trays) and placed in screened cages $(60 \times 30 \times 45) \mathrm{cm}$ where the adult emerged under laboratory conditions of $70 \pm 10$ relative humidity and $27 \pm 1{ }^{\circ} \mathrm{C}$ controlled temperature with 14:10 (light:dark). The adults were fed with $10 \%$ sugared solution and after 3-4 days periodically a pigeon placed in resting cages overnight for blood feeding (14).

\section{Preparation of the solution \\ Citric acid solution}

The stock solution of citric acid solution was prepared by dissolving ( $1 \mathrm{~g}$ ) of citric acid powder in $(5 \mathrm{ml})$ of distilled water and then completed to $(10 \mathrm{ml})$ of distilled water to obtain a stock solution with concentration of $10 \%$. From this stock solution different concentrations of 250, 500, 750 and 1000 ppm were prepared.

\section{Detergent solution}

The detergent solution was prepared by dissolving $(1 \mathrm{~g})$ of the detergent powder [(Super Topper, Turkey) Ingredients: Anionic Surfactans $16 \%$ STPP-Perfume-S. Carbonate-F.W.A., S.Silicate-S.Sulphate)] in $(5 \mathrm{ml})$ of distilled water and then completed to $(10 \mathrm{ml})$ of distilled water to obtain a stock solution with concentration of $10 \%$. From this stock solution different concentrations of 250, 500, 1000 and 1500 ppm were prepared.

\section{Sodium carbonate solution and Sodium bicarbonate solution}

The sodium carbonate solution and sodium bicarbonate solution were prepared in the same way as the citric acid solution was prepared, in order to obtain the sodium carbonate solution and sodium bicarbonate solution at a concentration of $10 \%$. From this stock solution, different concentrations of 2000, 4000, 6000 and 8000 ppm were prepared.

Stock solution of $100000 \mathrm{ppm}$ was prepared by dissolving $1 \mathrm{~g}$ of each substance used in this study in $10 \mathrm{ml}$ of distilled water.

20 healthy $3^{\text {rd }}$ instar larvae of Cx pipiens molestus were put in a disposable plastic cup containing 50 $\mathrm{ml}$ of treatment solution of four concentrations of citric acid 250, 500, 750 and $1000 \mathrm{ppm}$, four concentrations of detergent solution 250, 500, 1000, and $1500 \mathrm{ppm}$ and four concentrations for each of sodium carbonate and sodium bicarbonate 2000, 4000,6000 and 8000 ppm with 0.3 grams of rabbits food, using three replicates for each concentration with a control group represented by the presence of water and food only. The effect of the treatment solution was monitored by counting the dead larvae at the end of 24, 48, hours and continuing for 7 days.

\section{Calculation and data analysis:}

The percentage of mortality was calculated. The percentage of larval mortality was corrected according to the Abbott's equation (15), utilizing LDP-line to estimate the $\mathrm{LC}_{50}$ slope values in addition to the test of less significant difference LSD so as to make sure of the significance of the differences between the results.

Percentage mortality $=\frac{\text { Number of dead larvae }}{\text { Number of larvae in control }} \times 100$

Correct percent of mortality $=\frac{\mathrm{T}-\mathrm{C}}{100-\mathrm{C}} \times 100$

Where, $\mathrm{T}=$ The percentage of mortality in the treatment

$\mathrm{C}=$ The percentage of mortality in the control

\section{Results and Discussion:}

In this study, after one day of treatment the 1000 ppm concentration was the most effective on larval mortality were $85 \%$ followed by the concentration of $750 \mathrm{ppm}$ which killed $70 \%$ of mosquito larvae, while the concentration $250 \mathrm{ppm}$ caused a lower percentage of mortality $15 \%$. In the second day of experiment the concentration 1000 ppm gave mortality percent $100 \%$, while the concentration $750 \mathrm{ppm}$ gave mortality of a $100 \%$ in the fifth day of the experiment and the concentration $500 \mathrm{ppm}$ gave mortality percent $100 \%$ in sixth day. However, the concentration $250 \mathrm{ppm}$ caused a lower percentage of mortality $52.63 \%$ in the sixth day of the experiment compared to control group with a death rate of $5 \%$ ( Table 1). The $\mathrm{LC}_{50}$ value of citric acid was obtained as 2096. 
Table 1. The effect of citric acid solution on $3^{\text {rd }}$ instar larvae of Culex pipiens molestus $\mathrm{F}$.

\begin{tabular}{cccccc} 
Days & \multicolumn{5}{c}{ Concentrations ppm } \\
\cline { 2 - 6 } & 250 & 500 & 750 & 1000 & Control \\
& \multicolumn{5}{c}{ Mortality } \\
1 & 15 & 50 & 70 & 85 & 0 \\
2 & 25 & 65 & 80 & 100 & 0 \\
3 & 30 & 80 & 85 & 100 & 0 \\
4 & 40 & 90 & 90 & 100 & 0 \\
5 & 47.36 & 94.73 & 100 & 100 & 5 \\
6 & 52.63 & 100 & 100 & 100 & 5 \\
7 & 52.63 & 100 & 100 & 100 & 5
\end{tabular}

The concentrations $1500,1000 \mathrm{ppm}$ respectively are likely a significant reason for a higher percentage of killed larvae in the first day of experiment, which was $80,70 \%$ respectively. As for the concentrations 500 and $250 \mathrm{ppm}$, they gave a mortality percent of $15,0 \%$ respectively. In the third day of the experiment outweigh the concentration $1500 \mathrm{ppm}$ was found to kill all the larvae, as the percentage of killing was $100 \%$. The $1000 \mathrm{ppm}$ concentration killed $100 \%$ of the larvae in the fifth day of the experiment, but the concentrations 500, $250 \mathrm{ppm}$ caused percentage of mortality

$40,25 \%$ respectively in the fifth day of the experiment which remained constant until the seventh day. It is noteworthy that there was no mortality in the control group during the experiment for all concentrations ( Table 2). The $\mathrm{LC}_{50}$ value of detergents was obtained as 2715 .

Table 2. The effect of detergent solution on $3^{\text {rd }}$ instar larvae of Culex pipiens molestus $\mathrm{F}$.

\begin{tabular}{cccccc}
\hline & \multicolumn{5}{c}{ Concentrations ppm } \\
\cline { 2 - 6 } Days & 250 & 500 & 1000 & 1500 & Control \\
& \multicolumn{5}{c}{ Mortality percentage $\%$} \\
1 & 0 & 15 & 70 & 80 & 0 \\
2 & 5 & 25 & 75 & 90 & 0 \\
3 & 15 & 30 & 80 & 100 & 0 \\
4 & 20 & 35 & 95 & 100 & 0 \\
5 & 25 & 40 & 100 & 100 & 0 \\
6 & 25 & 40 & 100 & 100 & 0 \\
7 & 25 & 40 & 100 & 100 & 0 \\
\hline
\end{tabular}

After one day of treatment the $8000 \mathrm{ppm}$ concentration was the most effective on larval mortality which was $50 \%$. It was followed by the concentration of $6000 \mathrm{ppm}$ that caused the killing of $30 \%$ of mosquito larvae. Interestingly, the concentrations 4000, $2000 \mathrm{ppm}$ caused a lower percentage of mortality $10,0 \%$ respectively. In the third day of the experiment outweigh the concentration $8000 \mathrm{ppm}$ is killing all the larvae, where the percentage of killing was $100 \%$, while the concentration $6000 \mathrm{ppm}$ gave mortality of a $100 \%$ in the sixth day of the experiment. The 4000 ppm concentration killed $84.21 \%$ of the larvae in the sixth day of the experiment, compared to control group with a death rate of 5\%. Nonetheless, the concentration $2000 \mathrm{ppm}$ caused a lower percentage of mortality $5.26 \%$ only in the third day of the experiment which remained constant until the seventh day ( Table 3 ). The $\mathrm{LC}_{50}$ value of citric acid was obtained as 2096.

Table 3. The effect of sodium carbonate solution on $3^{\text {rd }}$ instar larvae of Culex pipiens molestus $\mathrm{F}$.

\begin{tabular}{cccccc} 
Days & \multicolumn{5}{c}{ Concentrations ppm } \\
\cline { 2 - 6 } & 2000 & 4000 & 6000 & 8000 & Control \\
& \multicolumn{5}{c}{ Mortality percentage \% } \\
1 & 0 & 10 & 30 & 50 & 0 \\
2 & 5 & 25 & 60 & 90 & 0 \\
3 & 5.26 & 47.36 & 68.42 & 100 & 5 \\
4 & 5.26 & 57.89 & 78.94 & 100 & 5 \\
5 & 5.26 & 73.68 & 89.47 & 100 & 5 \\
6 & 5.26 & 84.21 & 100 & 100 & 5 \\
7 & 5.26 & 84.21 & 100 & 100 & 5 \\
\hline
\end{tabular}

After one day of treatment the $8000 \mathrm{ppm}$ concentration was the most effective on larval mortality which was $40 \%$, followed by the concentration of $6000 \mathrm{ppm}$ which caused the killing of $10 \%$ only. In the third day of experiment the $8000 \mathrm{ppm}$ concentration killed $75 \%$ of the larvae and the concentration $6000 \mathrm{ppm}$ gave mortality $40 \%$, while the concentrations 4000, $2000 \mathrm{ppm}$ caused a lower percentage of mortality 10, 5\% respectively. In the fourth day of the experiment outweigh the concentration $8000 \mathrm{ppm}$ where the percentage of killing was $84.21 \%$, while the concentration 6000 ppm gave mortality of a $42.1 \%$ which remained constant until the seventh day compared to control group with a death rate of 5\% (Table 4). The $\mathrm{LC}_{50}$ value of sodium bicarbonate solution was obtained as 13960 .

Table 4. The effect of sodium bicarbonate solution on $3^{\text {rd }}$ instar larvae of Culex pipiens molestus $\mathbf{F}$.

\begin{tabular}{cccccc}
\hline Days & \multicolumn{5}{c}{ Concentrations ppm } \\
\cline { 2 - 5 } & 2000 & 4000 & 6000 & 8000 & Control \\
& \multicolumn{5}{c}{ Mortality percentage $\%$} \\
1 & 0 & 0 & 10 & 40 & 0 \\
2 & 0 & 5 & 25 & 50 & 0 \\
3 & 5 & 10 & 40 & 75 & 0 \\
4 & 0 & 5.26 & 42.1 & 84.21 & 5 \\
5 & 0 & 5.26 & 42.1 & 84.21 & 5 \\
6 & 0 & 5.26 & 42.1 & 84.21 & 5 \\
7 & 0 & 5.26 & 42.1 & 84.21 & 5 \\
\hline
\end{tabular}


Table 5. Less significant difference test (LSD)

\begin{tabular}{lcccccccc}
\hline \multicolumn{1}{c}{ Chemicals } & \multicolumn{9}{c}{ Days } & & & $\begin{array}{c}\text { Mean of } \\
\text { mortality }\end{array}$ \\
\hline Citric acid & 1 & 2 & 3 & 4 & 5 & 6 & 7 & 2.057 \\
Detergent & 8.800 & 2.000 & 1.000 & 1.000 & 1.200 & 0.400 & 0.000 & 1.514 \\
Sodium carbonate & 6.600 & 1.200 & 1.200 & 1.000 & 0.600 & 0.000 & 0.000 & 1.714 \\
Sodium Bicarbonate & 3.600 & 3.600 & 2.200 & 0.800 & 1.000 & 0.800 & 0.000 & 0.857 \\
Mean of days & 2.000 & 1.200 & 2.000 & 0.800 & 0.000 & 0.000 & 0.000 & \\
LSD & & & & & 0.2541 & & & 0.1921 \\
LSD for days and chemicals & & & & & 0.5083 & & & \\
\hline
\end{tabular}

According to the value of the LSD (Table 5) for the studied substances, it was found that the citric acid surpassed the rest of substances due to a significant difference between it and the rest of the substances used in the experiment. Likewise, sodium carbonate and detergents are superior to sodium bicarbonate due to the significant differences between them.

The results of the current study show that percentage of mortality increased proportionally with the increase of exposure period and concentration of solutions. The mechanism of action of detergents is to remove fat. The detergent molecules have a hydrophilic head and a hydrophobic tails, so the molecules are attracted to water from one end repelled by the other end. Hydrophobic attacks the fat molecule and surrounds it, pulling the molecules and their fats out . This is attributed to the fact that fat surrounds the body of the insect where the fat body composed of many big cells, called trophocytes. In the larval phases, the fat body occupies most of the body cavity which helps accelerate its destruction (16). The results of the current study are expected to be of significance when it comes to mortality rates after 24 hours up to 7 days of treatment by chemical solution. (16) reported that Lice sp., Melanoplus mexicanus, Periplaneta americana, Musca domestica and Ants were placed in a petri dish filled with washing powder solution whose ingredients are: sodium silicate, carboxymethylcellulose sodium, sodium sulphate, fluorescent materials, sodium telions sulphate. In different concentrations, the Lice sp. were killed by detergent solution in (17-22) seconds, Melanoplus mexicanus in (30-35) seconds, Periplaneta americana in (25-30) seconds and (1520) seconds for both Musca domestica and Ants. This study is consistent with the finding of (17) as dish washing liquids were toxic against the adult of Periplaneta americana after 24 hours of exposure. The knockdown effect of the detergents was found to be $70-78 \%$ in contact with detergents. However, when dipping $100 \%$ of the cockroaches, they are found to be knocked down and ultimately died at 24-houre exposure. (18) reported that the effect of detergent solutions with concentrations 23.3, 11.6 and 7.7 on two species of the hard ticks: Hyalomma ana. anatolicum and Ripicephlus turanicus takes several hours to cause mortality. It was found that the highest concentration of solution has the greatest activity. The highest concentration of detergent stopped the embryonic development of eggs, and hatching percentages was zero. The period of death was less in females full with eggs due to shield area is elongated and permeable. The results of this study are in agreement with (12) who reported that the detergent with the concentrations of $0.18,0.20,0.22,0.24, \mathrm{~g} / \mathrm{l}$ caused the killing of Aedes aegypti larvae 85.6, 89.6, 95.2 and 100\% respectively. (19) found a significant effect of dishes washing detergent on common Pistachio psylla, Agonoscena pistaciae, soil and plant with five treatments and four replicates. The results showed that the percentage of mortality was higher in $14^{\text {th }}$ and $21^{\text {st }}$ days after spraying. Furthermore, (20) reported that few makeup products like citric acid were applied to the skin of rats, mosquitoes were attracted towards, the results showed that Anopheles gambae was less attracted than Aedes aegypti towards the makeup products. The current study is similar to those conducted by (8), in which the citric acid was found to be effective on all tested stages of Aphis craccivora. This effectiveness was barely noticed after 2 hours, yet it increased after 12 hours. (10), noticed that the insecticidal activity of citric acid against the striped meal bug increased gradually to give the highest effectiveness after 18 days when the reduction percentage is 93.3 at 125 ppm. (21) reported that the mortality responses of Epiphyas postvittana larvae to immersion in solution of $0.5-5 \%$ sodium bicarbonate at $20-45{ }^{\circ} \mathrm{C}$ resulted in a maximum of $60 \%$ up to $100 \%$ mortality. (22), demonstrated that the soup solutions were prepared in 4 concentrations $10 \%, 20 \%, 30 \%, 40 \%$ then sprayed into 15 cockroaches. The soup solution has a lethal effect on the cockroaches with $\mathrm{LC}_{50}$ at $32 \%$ after 24 hours of treatment.

\section{Conclusions:}

The results of this study showed the acute toxicity and repellency of chemicals solution, 
particularly citric acid and detergents solution, against larvae of $C x$ pipiens molestus $\mathrm{F}$. at varied concentrations. Citric acid and detergents solution showed strong toxicity and repellent activities against $C x$ pipiens molestus larvae. Since these chemical solutions are safe, cheap, abundant and biodegradable, they can be used in the control of $C x$ pipiens molestus. The sodium carbonate and sodium bicarbonate were found to kill larvae of $C x$. pipiens molestus yet at high concentrations.

\section{Acknowledgment}

The authors are very grateful to the University of Mosul / College of Science for their provided facilities, which helped to improve the quality of this work.

\section{Authors' declaration:}

- Conflicts of Interest: None.

- We hereby confirm that all the Figures and Tables in the manuscript are mine ours. Besides, the Figures and images, which are not mine ours, have been given the permission for republication attached with the manuscript.

- The author has signed an animal welfare statement.

- Ethical Clearance: The project was approved by the local ethical committee in University of Mosul.

\section{References:}

1. World Health Organization. Current Zika product pipeline . Zica product landscape-03.03.16. 2016.

2. Molan A, Faraj AM, Hiday AM . Practical medical Entomology. Dar Erbil-printing and publishing 2012. 195 p.

3. Kemabonta KA, Adediran OI, Ajelara KO. The insecticida efficacy of the extracts of Piper nigrum (black pepper) and Curcumna longa (Turmeric) in the control of Anopheles gambiae Giles (Dip., Culicidae). Jordan J Bio. Sci.2018; 11(2):195-200.

4. Okbatinsae G, Haile A. In vitro studies of larvicidal effects of some plant extracts against Anopheles gambiae larvae larvae (Diptera:Culicidae). J Med Plant Res. 2017; 11(4):66-72 .

5. Brugman V, Hernandez-Triana L, Medlock J, Fooks A, Carpenter S, Johnson N. The role of Culex pipiens L. (Diptera:Culicidae) in virus transmission in Europe. Inter. J. Envir. Res. Public Health. 2018; 15(2):389-419.

6. Lumowa T, Nova P. Larvicidal activity of Syzygium polyanthum W. leaf extract against Aedes aegypti L. larvae. Prog. Health Sci. 2015; 5(1):102-106 .

7. Yaseen AT. The Effect of Alcoholic and Aqueous Extract of Piper nigrum on the Larvae of Culex pipiens molestus Forskal (Diptera:Culicidae). Baghdad Sci J. 2020; 17(1):28-33.
8. EL-kady A, Mohamed A, Mohamady A. Insecticidal activity of citric acid and its soluble powder formulations against Aphis craccivora under laboratory conditions. Egyp Acad J Bio Sci. 2010; 2(1):7-12.

9. Al-Qazwini YM, EL-Essa RA. Effect of use aggregation pheromone to reducing the amount of pesticides that needed to control American cockroaches Periplaneta Americana (L). ( Blattodea : Blattidae) IOP Conf. Series: Mater Sci Engin. 2019; $571: 1-15$

10. Mohamed G, EL-Kady A, Moharum F. Evalution of soluble poeder formulation of alum and citric acid as alternative pesticides against mealy bugs under filed conditions . Egyp Acad J Bio Sci. 2009; 1(1):69-72.

11. Allo NM, Mekhlif AF. Role of the predator Anisops sardea (Hemiptera: Notonectidae) in control mosquito Culex pipiens molestus (Diptera: Culicidae). Inter J Mosq Res. 2019; 6(2):46-50.

12. Sudarmaja M, Swastika K. Effectiveness of different detergents solutions as larviside for Aedes aegypti larvae. Bali Med J . 2015; 4(1):41-43.

13. Gill HK, Goyal G. Integrated pest management. InTech, Rijeka, Croatia, 2016. 156 p.

14. Mekhlif AF. Larvicidal efficacy and residual toxicity of selected xerophyte plants against Culex pipiens molestus mosquito. Int J Mosq Res. 2017; 4(3): 117-122.

15. Abbott W A. ethod of computing the effectiveness of an insecticides. J Eco Ento. 1925; 18:65-67 .

16. Afkar H. Effective of detergents of some species of Lice and house insects. Egyptian second international conference in chemistry: (2009); chemistry for human needs.9-12 November, Hurghada/Egypt.1-7.

17. Reza A, Din M, Parween S. Toxicity of dishwashing liquids against the American cockroach, Periplaneta Americana L. (Dictyoptera:Blattidae). Univ J Zool Rajshahi University. 2010; 29(1):51-56.

18. Hadi A. Study of some biochemical parameters and effect of detergents on Hyalomma ana. Anatolicum, Ripicephlus turanicus. Al-Mustansiriya . J Sci. 2010; 21(4):1-10 .

19. Panahi B, Basirat M, Hosseinifard S. The effect of liquid detergent on common pistachio psylla, Agonoscena pistaciae, soil and plant. Inter J Agric Crop Sci. 2013; 6(12):794-807 .

20. Khan S, Hanif H, Abbas Z, Saeed M, Ahmad M. Makeup ingredients (lactic acid, getyl alcohol, and citric acid) attract mosquitoes. Inter $\mathrm{J}$ Mosq Res. 2016; 3(1):10-13.

21. Lewthwaite S, Dentener P, Connolly P. Mortality of Epiphyas postvittana (Lepidoptera: Tortricidae) after exposure to sodium bicarbonate at elevated temperatures or combined with emulsifiers. New Zealand J Crop Hort Sci (1999) ; 27(2):83-90 .

22. Porusia M, Ratni RA, Dhesi SK. Toxicity of Commercially Available Bar Soap on American Cockroaches (Periplaneta americana) . Adv Bio Sci Res. 2019;8:161-164. 


\title{
Culex pipiens molestus Forskal الفعالية السمية لبعض المواد الكيمياوية على يرقات البعوض
}

خالدة عبد الله سليمان

\author{
الفت تحسين ياسين
}

قسم علوم الحياة، كلية العلوم، جامعة الموصل، الموصل، العراق.

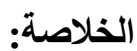

تضمنت الدر اسة الحالية إجر اء سلسلة من التجارب للتعرف على نأثثير اربع مو اد كيمياوية وهي حامض الليمون ، مسحوق الغسيل،

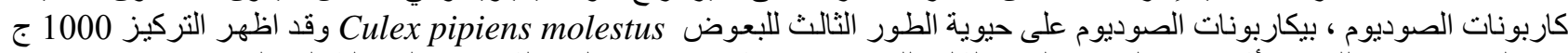

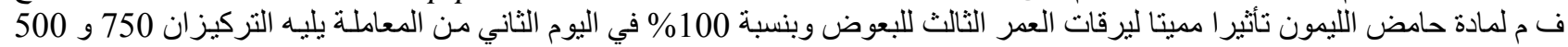

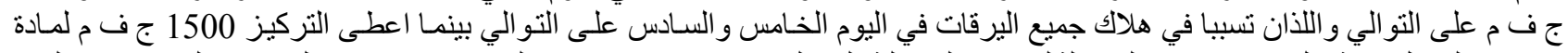

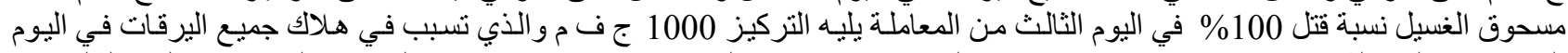

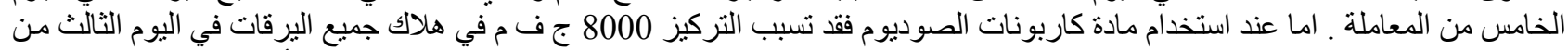

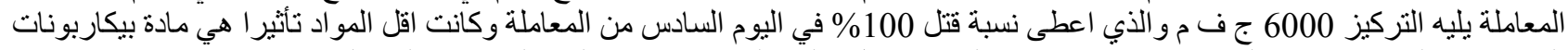
الصوديوم والتي اظهر فيها التركيز 8000 ج ف ف م اعلى نسبة قتل و التي بلغت 85\% في اليوم في اليوم الر ابع من المعاملة . الكلمات المفتاحية: حامض الليمون، مسحوق الغسيل، كاربونات الصوديوم، بيكاربونات الصوديوم، يرقات البعوض 